\title{
Early growth of camu-camu plants with nitrogen fertili- zation through fertirrigation
}

\author{
Carlos Abanto-Rodríguez ${ }^{1, *}$; Edvan Alves-Chagas ${ }^{2}$; Teresinha Costa-Silveira \\ de Albuquerque ${ }^{2}$; Roberto Tadashi-Sakazaki ${ }^{3}$; Wellington Farias-Araújo ${ }^{3}$; \\ Josimar da Silva-Chaves ${ }^{4}$ \\ ${ }^{1}$ Institute for Research of the Peruvian Amazon -IIAP, Federico Basadre Highway, Km 12,400, Yarinacocha, Ucayali, \\ Peru. \\ 2 Embrapa Roraima - Brazilian Agricultural Research Corporation, BR 174, Km 08, Industrial District, CEP: 69301-970, \\ Boa Vista-Roraima, Brazil. \\ ${ }^{3}$ Federal University of Roraima-Center for Agricultural Sciences - Cauame Campus BR $174 \mathrm{~s} / \mathrm{n}, \mathrm{km} \mathrm{12,} \mathrm{Monte} \mathrm{Cristo}$ \\ District. Brazil. \\ ${ }^{4}$ Federal Institute for Science and Technology of Roraima - IFRR/Novo Paraiso Campus. Brazil.
}

Received July 13, 2016. Accepted November 08, 2016.

\begin{abstract}
The objective of this study was to evaluate the effect of different doses of nitrogen (N), applied via fertirrigation, on the initial growth components of the camu-camu plants. It was conducted with the use of a randomized block experimental design with 5 treatments: $0 ; 40 ; 80 ; 120$ and $160 \mathrm{~kg} \mathrm{ha}^{-1}$ of $\mathrm{N}$, eight replicates and seven plants per experimental parcel. The experiment lasted for a period of 270 days. The diameter of stem $(\mathrm{mm})$ and the height of the plant $(\mathrm{cm})$ were evaluated every 30 days and the number of branches and total length of branches $(\mathrm{cm})$ were evaluated every 90 days. At the end of the experiment, chlorophyll $a$ index, dry mass of the leaves $(\mathrm{g})$, dry mass of the branches $(\mathrm{g})$, dry mass of the roots $(\mathrm{g})$, total dry mass $(\mathrm{g})$, and the Dickson Quality Index (DQI) were evaluated. According to the results, camu-camu plants that did not receive nitrogen fertilization had a lower initial growth and the doses of $\mathrm{N}$ significantly influenced all parameters evaluated in the camu-camu plants, including parameters from a linear and a quadratic model. The dose of 123 $\mathrm{kg} \mathrm{ha}^{-1}$ of $\mathrm{N}$, applied via fertirrigation, produced better quality camu-camu plants. Furthermore, greater doses caused depressive effects on growth of camu-camu plants in the first year of cultivation in firm ground conditions and the indirect measurement of chlorophyll $a$ index in camu-camu plants was suitable for the assessment of nutritional status in relation to $\mathrm{N}$.
\end{abstract}

Keywords: Myrciaria dubia; nitrogen; Dickson quality index; chlorophyll $a$ index.

\section{Introduction}

The camu-camu is a native fruit tree from the Amazon that has sparked the interest of producers and consumers alike, due to its high content of vitamin C, up to 7355.20 $\mathrm{mg}$ of ascorbic acid/100 $\mathrm{g}$ of pulp in the Brazilian Amazon (Chagas et al., 2015). The plant is found naturally on the margins of the majority of rivers, lakes, and creeks of the Amazon Basin, remaining submerged from 4 to 5 months during flood

* Corresponding author

E-mail: carforestal24@gmail.com (C. Abanto-Rodríguez). periods (Pinedo et al., 2010; Welter et al., 2011; Yuyama et al., 2011; Esashika et al., 2011). In light of the socioeconomic and nutritional potential of this fruit in the State of Roraima, there are favorable prospects for the development of the culture. As a species in the process of domestication, little is yet known about the agronomical management conditions necessary for its initial development on firm ground (Abanto et al., 2011). As such, 
it is important to generate technical information concerning initial fertilization with fertirrigation systems for the establishment camu-camu plants. Currently only results from greenhouse investigations with seedlings and in adult orchards utilizing conventional fertilization are available. This complicates the transfer of technology due to the lack of defined criteria for secure recommendations for fertilization in the first years of cultivation. Among the essential nutrients for growth and development of the plants is Nitrogen $(\mathrm{N})$, because it is a macronutrient absorbed and exported in large quantities by the plants. The absorption of $\mathrm{N}$ principally occurs in the form of nitrate $\left(\mathrm{NO}^{3-}\right)$ or ammonia $\left(\mathrm{NH}^{4+}\right)$, it participates directly in photosynthesis and in the increase in level of plant protein, and has a direct influence on the absorption and/or the distribution of practically all the other nutrients (Dechen and Nachtigall, 2006; Cantarella, 2007).

Nitrogen fertilization can be done with chemical composites in the nitric, ammoniacal and amidic forms. Among the commercial sources of the nutrient, urea is most notable due to the ease of access on the market, low cost per unit of $\mathrm{N}$, high solubility and compatibility for use in mixtures with other fertilizers (Malavolta, 2006; Santos et al., 2011; Smarsi et al., 2011).

Fertirrigation is the practice of applying fertilizers dissolved in irrigation water in a continual or intermittent form, permitting the application of nutrients directly at the location of greatest concentration of roots and in fractioned doses for increased efficiency of fertilization. Its use brings advantages such as the improvement of efficiency and uniformity of application linked to the uniformity of the irrigation system (Teixeira et al., 2007; Andrade, 2004; Dantas-Neto et al., 2013). Additionally, plants with correct fertirrigation quickly achieve the appropriate height and stem diameter necessary to effect a graft or formation pruning in fruit plants (Serrano et al., 2004). Based on the above, the objective of this research was to evaluate the effect of the different doses of nitrogen, applied via fertirrigation on the components of initial growth of the camu-camu plants in firm ground conditions in the region of the Roraima savannah.

\section{Materials and methods}

The research was conducted in the period from January to October 2013, in a total area of $2464 \mathrm{~m}^{2}$, at the Agua Boa Experimental grounds of EMBRAPA Roraima, situated at geographic reference coordinates $02^{\circ} 39^{\prime} 48.94$ " latitude north and $60^{\circ} 50^{\prime} 30.39^{\prime \prime}$ longitude west, and at an altitude of $90 \mathrm{~m}$ in the Municipality of Boa Vista, Roraima. The climate of the region is characterized as Aw-Tropical with a dry season, according to the Köppen classification, with average precipitation of $1700 \mathrm{~mm}$ ano $^{-1}$ concentrated in the months of April to September and an average annual temperature of between 26 and 28 ${ }^{\circ} \mathrm{C}$. The maximum monthly evapotranspiration, according to the Blaney - Criddle method is $141.2 \mathrm{~mm}$ in the month of January and the minimum is $103 \mathrm{~mm}$ in the month of June (Araújo et al., 2007).

Table 1

Chemical attributes of the soil at the Agua Boa experimental grounds

\begin{tabular}{|c|c|c|c|c|c|c|c|c|c|c|c|}
\hline $\mathrm{pH}$ & MO & $\mathrm{P}$ & $\mathrm{K}$ & $\mathrm{Ca}$ & $\mathrm{Mg}$ & $\mathrm{H}+\mathrm{Al}$ & SB & CEC & Sat bases & Sat Al & S \\
\hline $\mathrm{CaCl}_{2}$ & $\mathrm{~g} \mathrm{dm}^{-3}$ & $\mathrm{~g} \mathrm{dm}^{-3}$ & \multicolumn{6}{|c|}{ 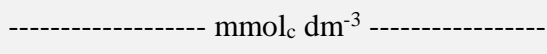 } & $\mathrm{V} \%$ & $\mathrm{~m} \%$ & $\mathrm{mg} \mathrm{dm} \mathrm{m}^{-3}$ \\
\hline 4.4 & 10 & 3 & 0.2 & 2 & 1 & 24 & 3 & 28 & 11 & 72 & 6 \\
\hline $\mathrm{Cu}$ & & $\mathrm{Zn}$ & & & $\mathrm{Fe}$ & & & B & & & Mn \\
\hline \multicolumn{12}{|c|}{ - } \\
\hline 0.2 & & 0.3 & & & 21 & & & 0.13 & & & 0.4 \\
\hline
\end{tabular}

Source: INPA (2013). 
The soil of the experimental area is classified as Yellow Latosol and presents the chemical attributes shown in Table 1, completed at the analysis laboratory of the National Institute of Amazonian Research (INPA) according to Embrapa-1998 methodology.

Based on the recommendations proposed Yuyama (2011), the area identified for the execution of the experiment was prepared beforehand by mowing, plowing and grading, so that all remnants of vegetal biomass on the surface level of the soil could be incorporated. As the soil presented a low $\mathrm{pH}$ and reduced levels of $\mathrm{P}, \mathrm{Ca}$ and $\mathrm{Mg}$, with elevated $\mathrm{Al}$ saturation and low saturation of the bases, soil correction was done with $1700 \mathrm{~kg} \mathrm{ha}^{-1}$ of dolomitic limestone and $400 \mathrm{~kg} \mathrm{ha}^{-1}$ of Simple Superphosphate (SS) containing $\mathrm{Ca}, \mathrm{Mg}$ and $\mathrm{P}$, dispersed by hand, after the preparation of the area. In the preparation of the holes with dimensions of $0.30 \mathrm{~m} \mathrm{x}$ $0.30 \mathrm{~m} \times 0.30 \mathrm{~m}$, an additional $300 \mathrm{~g}$ of lime and $100 \mathrm{~g}$ of SS/hole were applied. At the same time, $10 \mathrm{~g}$ of FTE-BR12 was added to enrich the soil with micronutrients, as this product is made up of the following chemical components: 9.0 to $9.2 \% \mathrm{Zn} ; 1.8$ to $2.17 \% \mathrm{~B} ; 0.80 \% \mathrm{Cu}$; $3.82 \% \mathrm{Fe} ; 2.0$ to $3.4 \% \mathrm{Mn}$ and $0.132 \%$ Mo. To satisfy the requirements for $\mathrm{K}$, a standard dose of potassium chloride of 40 $\mathrm{kg} \mathrm{ha}^{-1}$ was introduced in all the treatments. The camu-camu seedlings utilized in the experiment were sourced from plants of the Candeias population of the INPA germplasm bank. Shrubs smaller than 2.5 $\mathrm{m}$ in height characterize this population, with an irregular to dense crown (intermediary crown), and a trunk with branches from the soil or at $20 \mathrm{~cm}$ from the ground [1b]. The plantlets were transplanted to sacks containing $1 \mathrm{dm}^{3}$ of substrate composed of sand, soil and sawdust in proportions of 1:1:1 in May 2012. When the seedlings were seven months old and presented about 4 branches, with an average height per plant of $35.6 \mathrm{~cm}$ and 4.4 $\mathrm{mm}$ stem diameter they were transplanted to the holes prepared 25 days earlier.
Irrigation was done by a system of autocompensated drips operationalized by motorized pump, with automated system activation using the RAIN BIRD ${ }^{\circledR}$ control programmer. The system's outflow was linear at $6.81 \mathrm{~h}^{-1}\left(3.4 \mathrm{l} \mathrm{h}^{-1}\right.$ for each dripper spaced at every $50 \mathrm{~cm}$ ). The Venturi $3 / 4$ inch type injector was utilized for the injection of the fertilizers, operating at a 150-liters/hour rate of injection. The quantity of water applied was determined based on evapotranspiration estimated by Class A tank and the culture coefficient $[\mathrm{Kc}=4.5$ (recommended for the first year)], which were taken as a reference from the guava tree, as it is of the same family as the camu-camu (Teixeira et al., 2007).

The experimental delineation was done in randomized blocks with five treatments: T1-0; T2- 40; T3-80; T4-120 and T5-160 $\mathrm{kg} \mathrm{ha}^{-1}$ of $\mathrm{N}$, with eight replications and seven plants per experimental parcel (five used and two outlining controls). The treatments were applied via fertirrigation for 40 weeks, and the doses were distributed each 10 weeks, composed of $10 \% ; 20 \% ; 30 \%$ and $40 \%$ of the total corresponding treatment.

Evaluations were realized every 30 days, measuring the height of plants $(\mathrm{cm})$, and stem diameter $(\mathrm{mm})$, and every 90 days the number of branches and total length $(\mathrm{cm})$ of the branches were evaluated for each plant (these variables were analyzed in arrangements of parcels subdivided by time, with the five doses constituting the parcels, and the time constituting the sub parcels; there were 10 evaluations in the time for height and diameter, and four evaluations in the time for number and length of branches). At the end of the experiment, as of 270 DAT (days after transplant) evaluations of chlorophyll $a$ were done, utilizing the ClorofiLOG ${ }^{\circledR}$ brand electronic chlorophylometer operated according to manufacturer instructions (Falker, 2008). At the halfway point of every plant, readings were done on five leaves, based on the methodology described by El-Hendawy et al. (2005). Sub- 
sequently, the plants were collected and washed; following which the roots were separated from the aerial part (branches and leaves), to be placed in a dryer with forced air circulation at $65^{\circ} \mathrm{C}$, up until they reached a constant weight. Thereafter the dry mass of the samples was evaluated in grams (variables were analyzed in simple randomized block delineation).

With the results of the dry mass of the aerial part (DMAP), dry mass of the roots $(D M R T)$ and total dry mass (TDM), Plant height $(H)$ and stem diameter $(S D)$, the Dickson Quality Index (DQI) was determined utilizing the formula described by Gomes et al. (2003), defined by the expression:

$$
D Q I=T D M /[(H / D S)+(D M A P / D M R T)]
$$

The data was submitted to variance analysis and to polynomial regression ( $\mathrm{p}<$ 0.05 ) through the SISVAR computational program. Values which were not within the parameters of normalcy and homogeneity were transformed in $(\mathrm{x}+0.5)^{0.5}$.

\section{Results and discussion}

Height $(\mathrm{cm})$, diameter of stem $(\mathrm{mm})$, number and length of branches $(\mathrm{cm})$

The variance analysis of the height and the diameter of the stem (Table 2) of the camu-camu plants showed that there was significant influence of the $\mathrm{N}$ doses based on the F test $(\mathrm{p}<0.05)$. With regard to the interrelation, there was only significance in relation to the stem diameter, demonstrating that there was differentiation between treatments to the extent that the applications of $\mathrm{N}$ were done.

For the variance analysis of the characteristics: number and length $(\mathrm{cm})$ of branches (Table 3), there was significant influence $(p<0.05)$ based on the doses of $\mathrm{N}$, time of application and interaction of factors.

\section{Table 2}

Variance analysis (ANOVA) of the effect of $\mathrm{N}$ on the height $(\mathrm{cm})$ and diameter of the stem $(\mathrm{mm})$ of the camu-camu plants in the period of 270 days

\begin{tabular}{|c|c|c|c|c|c|}
\hline \multirow{2}{*}{ Source of variation } & \multirow{2}{*}{ GL } & SQ & QM & SQ & QM \\
\hline & & \multicolumn{2}{|c|}{ Height of plant $(\mathrm{cm})$} & \multicolumn{2}{|c|}{ Diameter stem (mm) } \\
\hline Doses (D) & 4 & 141.774 & $35.443^{*}$ & 10.473 & $2.608^{*}$ \\
\hline Residual 1 & 28 & 270.497 & 9.676 & 11.582 & 0.414 \\
\hline Time $(\mathrm{T})$ & 9 & 3119.201 & $346.577^{*}$ & 408.908 & $45.434^{*}$ \\
\hline T X D & 36 & 24.127 & $0.670^{\mathrm{ns}}$ & 8.479 & $0.235^{*}$ \\
\hline Residual 2 & 1915 & 1744.353 & 0.911 & 69.295 & 0.036 \\
\hline Total & 1992 & 5299.934 & & 508.737 & \\
\hline $\mathrm{CV}(\%) 1$ & & 38.20 & & 22.44 & \\
\hline $\mathrm{CV}(\%) 2$ & & 11.72 & & 6.64 & \\
\hline
\end{tabular}

Note: * Significant at $5 \%$ level; ${ }^{\text {ns }}$ not significant by ANOVA.

Table 3

Variance analysis (ANOVA) of the number and length $(\mathrm{cm})$ of stems of the camu-camu plants up to 270 days after planting on firm ground

\begin{tabular}{|c|c|c|c|c|c|}
\hline \multirow{2}{*}{ Source of variance } & \multirow{2}{*}{ GL } & SQ & QM & SQ & QM \\
\hline & & \multicolumn{2}{|c|}{ Number of branches } & \multicolumn{2}{|c|}{ Length of branches $(\mathrm{cm})$} \\
\hline Doses (D) & 4 & 87.945 & $21.986^{*}$ & 1375.820 & $343.955^{*}$ \\
\hline Residual 1 & 28 & 66.858 & 2.387 & 592.551 & 21.162 \\
\hline Time $(\mathrm{T})$ & 3 & 1394.358 & $464.786^{*}$ & 20140.482 & $6713.494 *$ \\
\hline T X D & 12 & 58.428 & $4.869^{*}$ & 841.597 & $70.133^{*}$ \\
\hline Residual 2 & 745 & 385.972 & 0.518 & 6830.652 & 9.168 \\
\hline Total & 792 & 1993.561 & & 30175.537 & \\
\hline $\mathrm{CV}(\%) 1$ & & 42.79 & & 40.22 & \\
\hline $\mathrm{CV}(\%) 2$ & & 19.93 & & 26.47 & \\
\hline
\end{tabular}

Note: ${ }^{*}$ Significant at $5 \%$ level by ANOVA. 
The doses of $\mathrm{N}$ significantly influenced the Height $(\mathrm{cm})$, diameter of stem $(\mathrm{mm})$ of the camu-camu plants, presenting a model linear and quadratic response. For the height (Figure 1a) and diameter of stem (Figure 1b), maximum values of 116.68 $\mathrm{cm}$ and $14.06 \mathrm{~mm}$ were observed in response to the doses of 120 and $80 \mathrm{~kg} \mathrm{ha}^{-1}$ of $\mathrm{N}$ respectively, as of 270 DAT. The doses of $\mathrm{N}$ and the times of application significantly influenced the number and length of the branches of the camu-camu
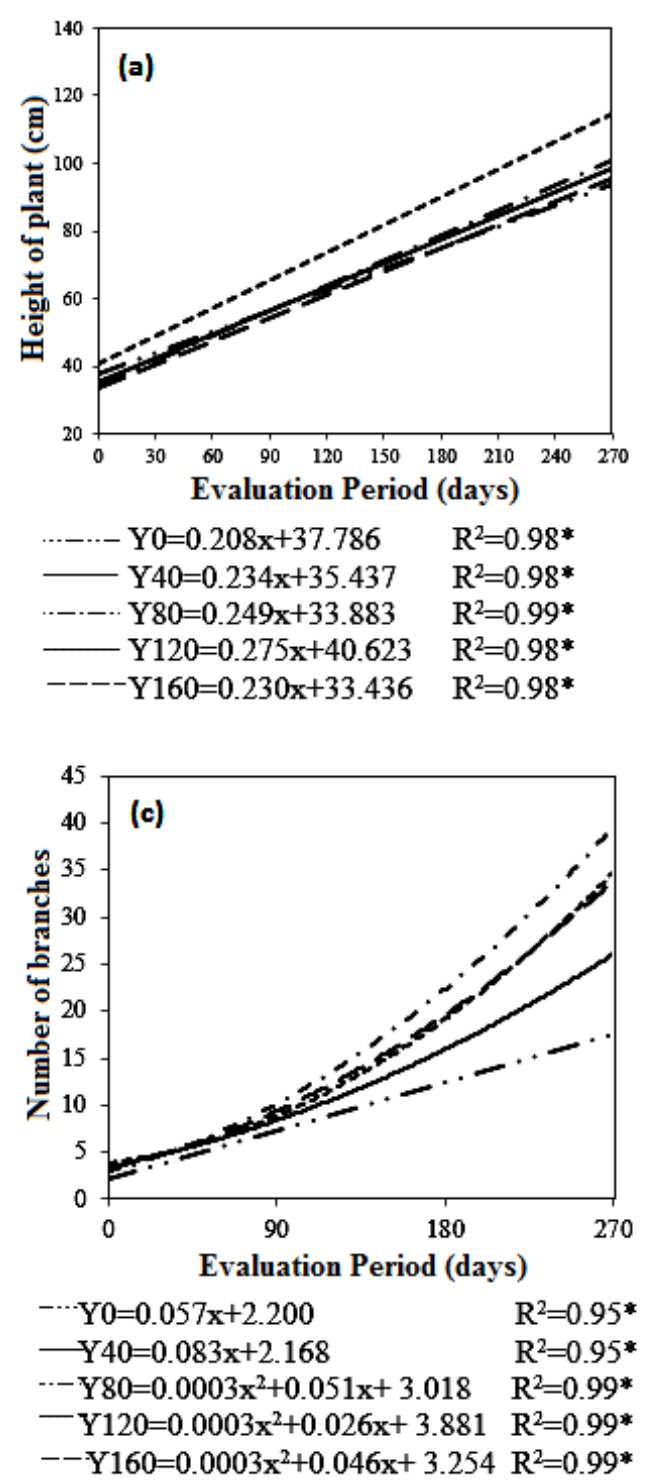

plants, presenting a model of quadratic response (Figure 1c and 1d).

The camu-camu plants treated with doses of $80 \mathrm{~kg} \mathrm{ha}^{-1}$ of $\mathrm{N}$ presented an average of 39 branches while the control plants presented 18 branches on average. The length of the branches was significantly larger in the plants that received the dose $120 \mathrm{~kg} \mathrm{ha}^{-1}$ of $\mathrm{N}$, achieving an average total length of $467.78 \mathrm{~cm}$ (Figure 2a), which represents an addition of $266.94 \mathrm{~cm}$ in relation to the control (Figure $2 \mathrm{~b}$ ).
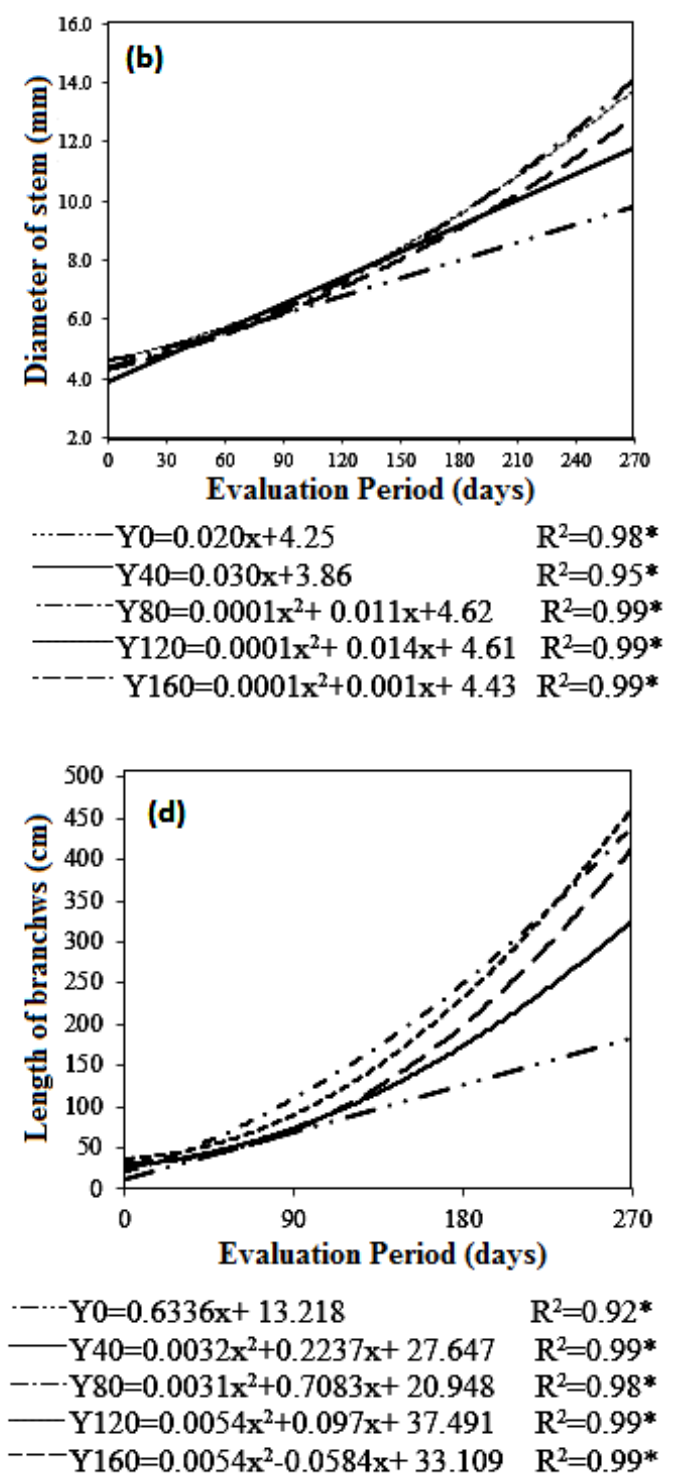

Figure 1. Effect of the doses of $\mathrm{N}$ on: (a) height (cm); (b) diameter of stem (mm); (c) number of branches, and (d) length $(\mathrm{cm})$ of branches of the camu-camu plants. 

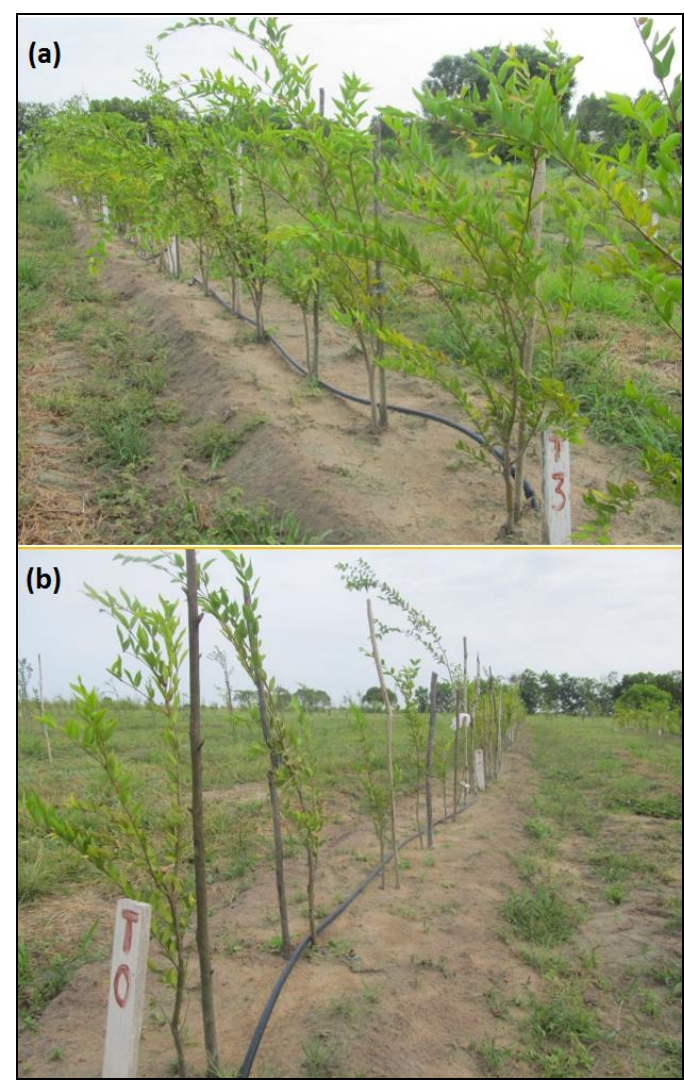

Figure 2. Camu-camu plants (a) with nitrogen (b) without nitrogen.

Upon observing Figure 1 it was established that the plants presented significantly linear and quadratic growth responses ( $p<$ $0.05)$ to receiving fertilization with nitrogen during the evaluation period. It may be inferred also that the treatments with different doses of nitrogen began to have an effect as of 25 to 30 days after the first fertirrigation. While the plants did not present great differentiation based on the different doses of $\mathrm{N}$ for height and diameter of stem, there was a greater emission of branches and longer length of the same, in plants fertilized in relation to the control.

In the present study, it is evident that the growth of the camu-camu plants that did not receive nitrogen was compromised, confirming what other authors obtained with other crops (Cruz et al., 2006; Malavolta, 2006). In addition, these authors related that nitrogen deficiency affected the growth and development of plants, principally because it is composed of proteins and chlorophylls. Nitrogen deficiency does not allow the plants to express their full potential, thus occurring significant reductions in the rate of foliar formation and expansion.

These results are similar to those obtained by Santos et al. (2011), with the crop of the Passiflora edulis $f$, when they utilized ammonium nitrate, urea and ammonium sulfate, boosting the number of leaves and the total foliar area of the plants. Similar effects were obtained by Souza et al. (2007) working with the production of Tamarindus indica L. seedlings, where they observed that the length of the aerial part increased with the elevation of the doses of urea. Also, Mendonça et al. (2010) noted positive effects on the height of the grafted stakes of the Anacardium occidentale with increased doses of Nitrogen.

\section{Chlorophyll a Index}

The index of chlorophyll a, determined at 270 DAT of the camu-camu plants in firm ground conditions, presented significant quadratic responses in relation to the doses of $\mathrm{N}(\mathrm{p}<0.05)$. The maximum point for the chlorophyll $a$ index (37.15) was obtained at an estimated dose of $109 \mathrm{~kg} \mathrm{ha}^{-1}$ of $\mathrm{N}$ (Figure 3 ).

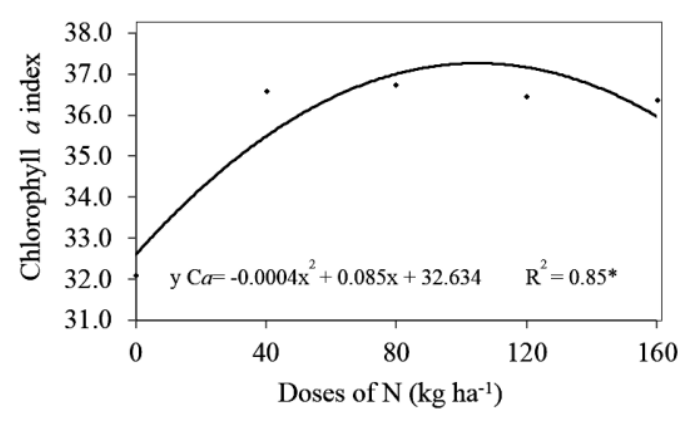

Figure 3. Effect of the doses of $\mathrm{N}$ on the Chlorophyll $a$ Index of the camu-camu plants.

In the present study, it is worth noting that the smaller doses of $\mathrm{N}$ presented lower indices of chlorophyll and the higher doses of $\mathrm{N}$ provoked a depressive effect on the 
chlorophyll $a$ index, as the plants fertilized with high doses exhibited chlorotic leaves. The results found in relation to chlorophyll $a$ in this study concur with those Silva et al. (2011), when they indicate that the intensity of the green color (chlorophyll) is related to the level of nitrogen in the leaves and the plants cultivated with inadequate quantities of nitrogen can suffer a reduced content on the chlorophyll index.

It study was also observed positive and significant correlation coefficient according to Pearson $\left(\mathrm{R}^{2}=0.95\right)$ between the Chlorophyll $a$ Index and leaf $\mathrm{N}$ content in the plant. This positive correlation is mainly attributed to the fact that 50 to $70 \%$ of the total $\mathrm{N}$ of the sheet members are enzymes that are associated with chloroplasts (Silva et al., 2011). Similar results were observed in Psidium guajava (Dias et al., 2012) and Ananas comosus L. Merril (Leonardo et al., 2013), which concluded that there was a positive correlation between chlorophyll content and content $\mathrm{N}$ in the leaf and also to the production of dry matter, indicating that the indirect measurement of chlorophyll was suitable for the assessment of nutritional status in relation to nitrogen.

Dry mass (g) of the leaves (DMLV), branches (DMB) and roots (DMRT) and total dry mass (g) (TDM)

The variance analysis for the dry mass $(\mathrm{g})$ of the leaves (DMLV), branches (DMB) and roots (DMRT) and total dry mass (g) (TDM) of the camu-camu plants were shown to have significant influence in relation to the doses of $\mathrm{N}$, based on the $\mathrm{F}$ test $(\mathrm{p}<0.05)$ (Table 4).

The dry mass (g) of the leaves (DMLV), branches (DMB) and roots (DMRT) and total dry mass (g) (TDM) of the camucamu plants presented significant quadratic responses to the doses of $\mathrm{N}$ (Figure 4). It may be observed that for TDM (g), the dose of $128 \mathrm{~kg} \mathrm{ha}^{-1}$ of $\mathrm{N}$ provided the maximum value of $365.38 \mathrm{~g}$, which signified an addition of $266.78 \mathrm{~g}$ in relation to the control. The DMB (g) with the dose of $112 \mathrm{~kg} \mathrm{ha}^{-1}$ of $\mathrm{N}$ achieved a maximum value of $261.14 \mathrm{~g}$, generating a gain of $200.12 \mathrm{~g}$ in relation to the control. For the DMRT $(\mathrm{g})$, the dose of $126 \mathrm{~kg} \mathrm{ha}^{-1}$ of $\mathrm{N}$ provided a maximum value of 65.52 which represented a gain of $39.38 \mathrm{~g}$ in relation to the control and lastly, for DMLV (g) the dose of $113 \mathrm{~kg} \mathrm{ha}^{-1}$ of $\mathrm{N}$ gave the maximum value corresponding to $60.50 \mathrm{~g}$, being a gain of $50.36 \mathrm{~g}$ in relation to the control.

A depressive effect on the TDM was also observed with doses higher than $128 \mathrm{~kg}$ $\mathrm{ha}^{-1}$ of $\mathrm{N}$ (Figure 2). In similar fashion Menegazzo et al. (2011), also found depressive quadratic effects with the increase of the doses of $\mathrm{N}$ on the dry mass of the aerial part of the plant when working on the production of Carica papaya $\mathrm{L}$. seedlings.

These effects can be explained by the elevation of the osmotic pressure in the plant, causing damage to the roots and negatively affecting the absorption of nutrients, with effects on the aerial part of the plant (Malavolta, 2006).

\section{Table 4}

Summary of the variance analysis (ANOVA) for the dry mass ( $g$ ) of the leaves (DMLV), branches (DMB) and roots (DMRT) and total dry mass (g) (TDM) of the camu-camu plants as of 270 days after planting in firm ground conditions

\begin{tabular}{lccccc}
\hline \multirow{2}{*}{ Source of variation } & \multirow{2}{*}{ GL } & \multicolumn{4}{c}{ Mean Square } \\
\cline { 3 - 5 } & & DMLV & DMB & DMRT & TDM \\
\hline Doses & 4 & $3904.17^{*}$ & $57827.47^{*}$ & $2149.062^{*}$ & $121329.19^{*}$ \\
Block & 7 & 233.950 & 6454.38 & 459.06 & 12803.59 \\
\hline Residual & 28 & 140.49 & 2738.81 & 139.49 & 5184.17 \\
\hline CV $(\%):$ & & 26.30 & 27.14 & 22.87 & 24.87 \\
\hline
\end{tabular}

Note: ${ }^{*}$ Significant at $5 \%$ level by ANOVA. 


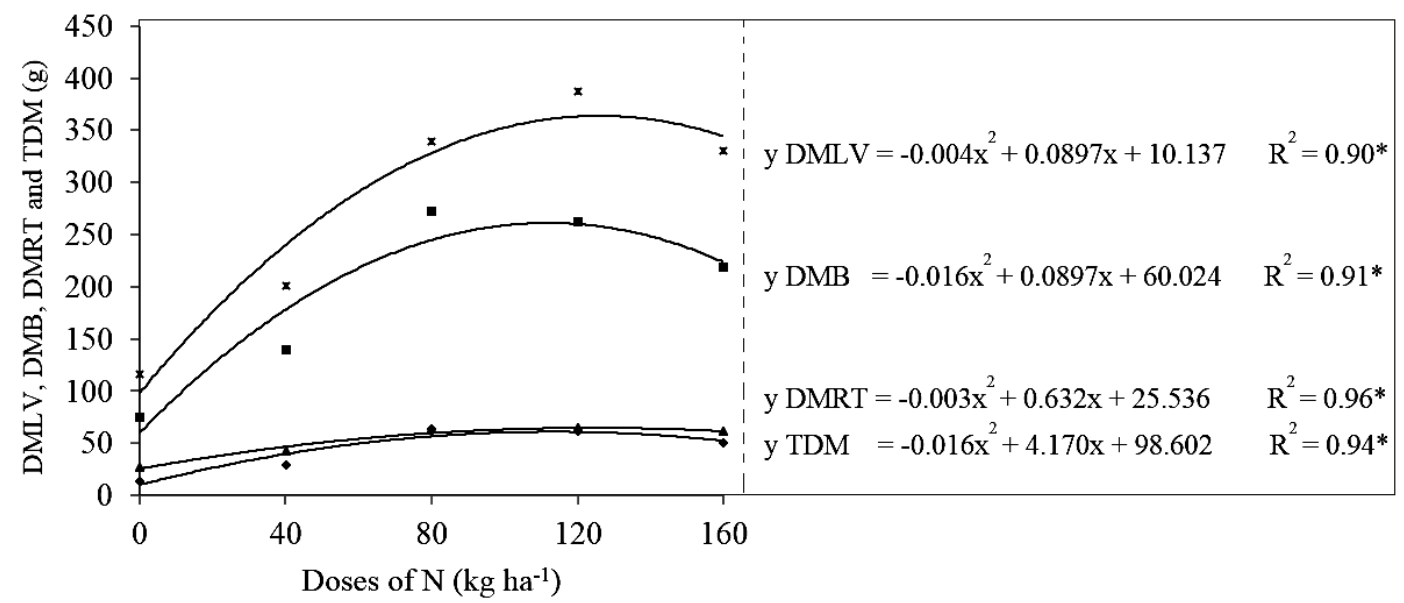

Figure 4. Effect of the doses of $\mathrm{N}$ on dry mass (g) of the leaves (DMLV), branches (DMB) and roots (DMRT) and total dry mass (g) (TDM) of the camu-camu plants.

Using elevated doses of urea [CO $\left.\left(\mathrm{NH}_{2}\right)\right]$ acidifies the substrate, since the breakdown of the urea releases $\mathrm{H}^{+}$provoking toxicity in the plants due to an excess of biuret, causing a lowering of the $\mathrm{pH}$ of the soil during the process of nitrification of the urea (Malavolta, 2006).

\section{Dickson Quality Index (DQI)}

In the present study, the DQI presented a significant quadratic response $(\mathrm{p}<0.05)$ to the supply of $\mathrm{N}$. The dose of $123 \mathrm{~kg} \mathrm{ha}^{-1}$ presented the maximum DQI of 27.89 . Above this dosage, the characteristic suffered a depressive effect (Figure 5).

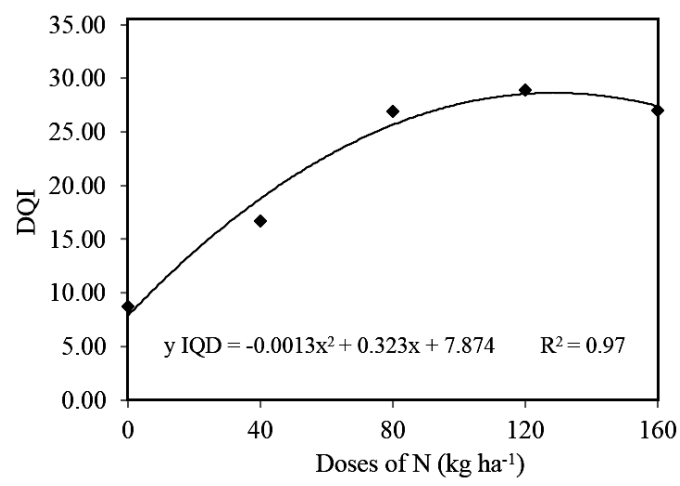

Figure 5. Effect of the doses of $\mathrm{N}$ on the Dickson Quality Index (DQI) of the camucamu plants.

This index is traditionally utilized in the production of seedlings of forest species, but the same characteristics which com- pose the DQI are important for the production of fruit plant seedlings (Dias et al., 2012). Also, being important for usage in evaluation of initial growth of fruit plants in the field. In this regard the higher the DQI, the better the quality of the plant with 0.20 as the minimum value (Gomes et al., 2003).

In this study, they were determined different doses of $\mathrm{N}$ for each variable studied, which are between 80 and $128 \mathrm{~kg}$ $\mathrm{ha}^{-1}$, however from the technical point it can be stated that the best dose of $\mathrm{N}$ fertilization for plants of camu-camu is to $123 \mathrm{~kg} \mathrm{ha}^{-1}$ for the first year of cultivation, since promoted the highest Dickson Quality Index. This indicator is very accurate because it allows better evaluate the morphological differences between plants. Likewise combines several morphological attributes into a single value that is used as an index of quality; It is that the higher the index value will be a better quality plant. Used for calculating total plant dry weight, height, basal diameter, dry weight of shoot and root dry weight (Gomes et al., 2003). Similar results were obtained by Dias et al. (2012), working with nitrogen fertilization in the production of Psidium guajava seedlings in a commercial nursery and Cruz et al. (2006), working with nitrogen fertilization in the production of Samanea inopinata (Harms) Ducke. 


\section{Conclusions}

Under the experimental conditions in which this work was conducted it is concluded that the different nitrogen doses applied via fertirrigation had an effect linear and quadratic in diameter of stem $(\mathrm{mm})$, height of the plant $(\mathrm{cm})$, number of branches and total length of branches $(\mathrm{cm})$, Dickson Quality Index (IQD), chlorophyll $a$ index and total dry mass (g).

The dose of $123 \mathrm{~kg} \mathrm{ha}^{-1}$ of nitrogen applied via fertirrigation, produced better quality camu-camu plants and it is concluded that doses larger than this, caused depressive effects on growth of camu-camu plants in the first year of cultivation in firm ground conditions.

The indirect measurement of chlorophyll $a$ index, in camu-camu plants was suitable for the assessment of nutritional status in relation to nitrogen.

Based on the results, future studies will have to be made to determine nutritional requirements in each phenological stage of the camu-camu plants cultivated in Boa Vista-Roraima.

\section{Acknowledgements}

The authors which to express their gratitude to the Coordination for Enhancement of Academically Qualified Personnel - CAPES, the Nation Council for Scientific and Technological Development - CNPq and the Brazilian Agricultural Research CorporationEmbrapa Roraima for the financial assistance in the present research and the Federal University of Roraima for the valuable support in the academic qualification of the principal author.

\section{References}

Abanto, R.C.; Oliva, C.; Domínguez, G.; Meza, A.; Chagas, A. E. 2011. Fertirriego en la producción del camu camu (Myrciaria dubia HBK Mc Vaugh) en la estación experimental del IIAP, Ucayali, Perú. Scientia Agropecuaria 2: 157 - 167.

Andrade, B.M. 2004. Efeito da fertirrigação com nitrogênio e potássio sobre os teores de nutrientes em um solo cultivado com gravioleira. Revista Ciência Agronômica 35(2): 410-417.

Araújo, F.W.; Costa, A.A.S.; Santos, E.A. 2007. Comparação entre métodos de estimativa da evapotranspiração de referência $\left(\mathrm{ET}_{\mathrm{O}}\right)$. Revista Caatinga 20(4): 84-88.
Chagas, E.A.; Lozano, R.M.B.; Chagas, P.C.; BacelarLima, C.G.; García, M.I.R.; Oliveira, J.V.; Souza, O.M.; Morais, B.S.; Araujo, M.C.R. 2015. Intraspecific variability of camu-camu fruit in native populations of northern Amazonia. Crop Breeding and Applied Biotechnology 15: 265-271.

Cantarella, H. 2007. Nitrogênio. In: Novais, R.F.; Alvares, V.H.; Barros, N.F.; Fontes, R.L.F.; Cantarutti, R.B.; Neves, J.C.L.. Fertilidade do Solo. 1.ed. Viçosa: Sociedade Brasileira de Ciência do Solo. Cap. 7, p. 375-470.

Cruz, C.A.A.; Paiva, H.N.; Guerrero, C.R.A. 2006. Efeito da adubação nitrogenada na produção de mudas de sete cascas (Samanea inopinata (Harms) Ducke). Rev. Árvore 30(4): 537-546.

Dantas-Neto, J.; Maciel, J.L.; Alves, A.D.S.; Azevedo, C.A.B.; Fernandes, P.D.; Lima, V.L.A. 2013. Teores de macronutrientes em folhas de goiabeira fertirrigadas com nitrogênio. Revista Brasileira de Engenheira Agrícola e Ambiental 17(9): 962-968.

Dechen, A.R.; Nachtigall, G. R. 2006. Micronutrientes. In: FERNANDES, M.S. (Ed.) Nutrição Mineral de Plantas. Viçosa: Sociedade Brasileira de Ciência do Solo. Cap. 13, p.327-354.

Dias, M.J.T.; Souza, H.A.; Natale, W.; Modesto, V.C.; Rozane, D.E. 2012. Adubação com nitrogênio e potássio em mudas de goiabeira em viveiro comercial. Semina: Ciências Agrárias, Londrina 33(1): $2837-$ 2848.

El-hendawy, S.; Hu, Y.; Schimidhalter, U. 2005. Growth, ion content, gas exchange, and water relations of wheat genotypes differing in salt tolerances. Australian Journal of Agricultural Research 56: 123-134.

Esashika, T.; Oliveira, L.A.; Moreira, F.W. 2011. Teores foliares de nutrientes em plantas de camucamuzeiro (Myrciaria dubia (H.B.K.) McVaugh) submetidas a adubação orgânica, mineral e foliar. Revista Brasileira de Ciências Agrárias 6(3): 391-400.

Falker. 2008. Automação Agrícola Ltda. Manual do medidor eletrônico de teor clorofila (ClorofiLOG / CFL 1030). Porto Alegre, Falker Automação Agrícola. $33 \mathrm{p}$.

Gomes, J.M.; Couto, L.; Leite, H.G.; Xavier, A.; Garcia, S.L.R. 2003. Parâmetros morfológicos na avaliação da qualidade de mudas de Eucalyptus grandis, Revista Árvore 26 (6): 655-664.

INPA - Instituto Nacional de Pesquisas da Amazônia. 2013. Laboratório temático de Análise de solos e plantas. Manaus -AM, Brasil.

Leonardo, F.A.P.; Pereira, W.E.; Silva, S.M.; Costa, J.P. 2013. Teor de clorofila e índice spad no abacaxizeiro cv. Vitória em função da adubação nitrogenada. Revista Brasileira de Fruticultura 35 (2): 377-383.

Malavolta, E. 2006. Manual de nutrição mineral de plantas. São Paulo: Agronômica Ceres. 638 p.

Mendonça, V.; Tosta, M.S.; Mendonça, L.F.M.; Biscaro, G.A.; Freitas, P.S.C.; Pareira, E.C.; Leite, A.G. 2010. Doses crescentes de nitrogênio sobre o crescimento inicial de porta-enxertos de cajueiro gigante. Revista Agrarian, Dourados 3(8): 95-103.

Menegazzo, M.L.; Oliveira, A.C.; Silva, E.A. 2011. Adubação nitrogenada na produção de mudas de mamoeiro. Revista Agrarian, Dourados 4(13): 189196.

Pinedo, P.M.; Delgado, V.C.; Farroñay, P.R.; Imán, C.S.; Villacréz, V.J.; Faching, M.L.; Oliva, C.C.; Abanto, R.C.; Bardales, L.R.; Vega, V.R. 2010. CAMUCAMU (Myrciaria dubia - Mirtaceae); Libro. Aportes para su aprovechamiento en la Amazonia Peruana 1(1): $135 \mathrm{p}$. 
Santos, P.C.C.; Lopes, L.C.; Freitas, S.J.; Sousa, L.B.; Carvalho, J.A.C. 2011. Crescimento inicial e teor nutricional do maracujazeiro amarelo submetido à adubação com diferentes fontes nitrogenadas. Revista Brasileira de Fruticultura Num. especial: 722-728.

Serrano, L.A.L.; Marinho, C.S.; Carvalho, A.J.C.; Monnerat, P.H. 2004. Efeito de sistemas de produção e doses de adubo de liberação lenta no estado nutricional de porta-enxerto cítrico. Revista Brasileira de Fruticultura 26(3): 524-528.

Silva, M.C.C.; Coelho, F.S.; Braun, H.; Fontes, P.C.R. 2011. Índice SPAD em função de diferentes horários e posições no folíolo da batata sobre fertilização nitrogenada. Revista Ciência Agronômica, Fortaleza 42 (4): 971-977.

Smarsi, R.C.; Oliveira, G.F.; Reis, L.L.; Chagas, E.A.; Pio, R.; Mendoça, V.; Chagas, P.C.; Curi, P. N. 2011. Efeito da adubação nitrogenada na produção de mudas de lichieira. Revista Ceres, Viçosa 58(1): 129-131.
Souza, H.A.; Pio, R.; Chagas, E.A.; Reis, J.M.R.; Rodrigues, H.C.A.; Ramos, J.D.; Mendonça, V. 2007. Doses de nitrogênio e fósforo na formação de mudas de tamarindo. Revista Bioscience Journal 23(1): 59-64.

Teixeira, L.A.J.; Natale, W.; Martins, A.L.M. 2007. Nitrogênio e potássio via fertirrigação e adubação convencional - estado nutricional das bananeiras e produção de frutos. Revista Brasileira de Fruticultura 29(1): 153-160.

Welter, M.K.; Melo, V.F.; Bruckner, C.H.; Góes, H.T.P.; Chagas, E.A.; Uchôa, S.C.P. 2011. Efeito da aplicação de pó de basalto no desenvolvimento inicial de mudas de camu-camu (Myrciaria dubia H.B.K. McVaugh). Revista Brasileira de Fruticultura 33(3): 922-931.

Yuyama, K.A. 2011. Cultura de camu-camu no Brasil. Revista Brasileira de Fruticultura 33 (2): 335-690.

Yuyama, K.; Mendes, N.B.; Valente, J.P. 2011. Longevidade de sementes de camu-camu submetidas a diferentes ambientes e formas de conservação. Revista Brasileira de Fruticultura 33(2): 601-607. 